\title{
Evaluation of the Development of Rural Inclusive Finance: A Case Study of Baoding, Hebei province
}

\author{
Ziqi Yang ${ }^{1}$, Xiaoxiao $\mathrm{Li}^{1}$ \\ Hebei Finance University, Baoding, Hebei Province, China
}

Keywords: inclusive finance; evaluation; rural inclusive finance; IFI index method

\begin{abstract}
Inclusive Finance", means that everyone has financial needs to access high-quality financial services at the right price in a timely and convenient manner with dignity. This paper uses IFI index method to evaluate the development level of rural inclusive finance in various counties of Baoding, Hebei province in 2016, and finds that rural inclusive finance in each country has a low level of development, banks and other financial institutions have few branches and product types, the farmers in that area have conservative financial concepts and rural financial service facilities are not perfect. In response to these problems, it is proposed to increase the development of inclusive finance; encourage financial innovation; establish financial concepts and cultivate financial needs; improve broadband coverage and accelerate the popularization of information.
\end{abstract}

\section{Introduction}

"Inclusive Finance", means that everyone with financial needs to access high-quality financial services at the right price in a timely and convenient manner with dignity. This paper uses IFI index method to evaluate the development level of rural Inclusive Finance in various counties of Baoding, Hebei province in 2016, and finds that rural Inclusive Finance in each country has a low level of development, banks and other financial institutions have few branches and product types, and the farmers in that area have conservative financial concepts and rural financial service facilities are not perfect.In response to these problems, it is proposed to increase the development of Inclusive Finance;encourage financial innovation,; establish financial concepts and cultivate financial needs; improve broadband coverage and accelerate the popularization of information.

\section{The Evaluation of Rural Inclusive Financial Development}

\subsection{Measurement method of rural inclusive financial development level.}

As early as 2008, Sarma constructed the Inclusive Financial Development Index (IFI) to measure the development level of Inclusive Finance in a region. His approach is to divide the inclusive financial field into n dimensions, and use Ai to represent the i Dimensions.

$$
A_{i}=\frac{x_{i}-m_{i}}{M_{i}-m_{i}}
$$

In this formula, $x_{i}$ represents the actual value of ${ }^{A_{i}}$, and $M_{i}, m_{i}$ represent the maximum and minimum values of the i Dimension, respectively. ${ }_{i} \in\left[m_{i}, M_{i}\right], A_{i} \in[0,1] 0$ and 1 are the two extreme values of $A_{i} ; A_{i}=0$ indicates that the region has complete financial exclusion in the i-th dimension. Under this dimension, the inclusive financial level is not developing well. $A_{i}=1$ indicates that the region does not have financial exclusion in the i-th dimension. Under this dimension, the inclusive financial development is the best.

The formula of IFI is 


$$
I F I=\sum_{i=1}^{n} \omega_{i} A_{i}
$$

Assuming that each dimension is given the same weight, then the equation (2) as follows:

$$
I F I=\frac{1}{n} \sum_{i=1}^{n} \frac{x_{i}-m_{i}}{M_{i}-m_{i}}
$$

Measurement of the development level of rural Inclusive Finance in Baoding

Based on the research on the development of Inclusive Finance at domestic and foreign,We constructthe measurement index system of inclusive financial development level in Baoding.Specifically,theevaluation system is mainly developed from four dimensions, $n=4$ :

$$
I F I=\frac{1}{4} \sum_{i=1}^{4} \frac{x_{i}-m_{i}}{M_{i}-m_{i}}
$$

This paper divides the development level of Inclusive Finance into four dimensions to measure, namely $A_{1}, A_{2}, A_{3}, A_{4} A_{1}$ indicates the convenience of financial services,.It measured by the number of bank outlets per 10,000 people- ${ }^{a_{1}}$ and the number of rural financial practitioners per 10,000- ${ }^{a_{2}}$.Among them, the number of bank outlets includes policy banks, credit unions,commercial banks, and rural banks. Set the same weight for both indicators, then $x_{1}=\frac{a_{1}+a_{2}}{2}$.

$A_{2}$ indicates the use of financial services. It is expressed by the per capita deposit amount $-b_{1}$, the per capita loan amount- $b_{2}$.Set the same weight for both metrics, then actual value of $A_{2}$ is $x_{2}=\frac{b_{1}+b_{2}}{2} A_{3}$ indicates the efficiency of financial services development. $A_{3}$ is expressed by $c_{1}$ -savings deposit balance / regional GDP, $c_{2}$ - loan total / regional GDP.Set the same weight for both metrics, then the actual value is $x_{3}=\frac{c_{1}+c_{2}}{2} . A_{4}$ indicates the financial service environment. $A_{4}$ is expressed by the broadband coverage rate- $d_{1}$ and the urbanization rate- ${ }^{2}$. Set the same weight for both metrics, Then the actual value is $x_{4}=\frac{d_{1}+d_{2}}{2}$.

According to the formula (1) $x_{1} x_{2} x_{3} x_{4}$ are shown in the table below.

Table 1 Four-dimensional actual values of counties in Baoding

\begin{tabular}{lccccllllll}
\hline county & $x_{1}$ & $x_{2}$ & $x_{3}$ & $x_{4}$ & county & $x_{1}$ & $x_{2}$ & $x_{3}$ & $x_{4}$ \\
Laishui County & 3.33 & 34844.95 & 1.94 & 28.80 & $\begin{array}{l}\text { Anxin } \\
\text { County }\end{array}$ & 3.35 & 22595.17 & 1.76 & 34.91 \\
Fuping County & 4.01 & 38422.25 & 2.29 & 22.68 & $\begin{array}{l}\text { Yi } \\
\text { County }\end{array}$ & 4.07 & 21705.01 & 1.04 & 23.66 \\
$\begin{array}{l}\text { Dingxing } \\
\begin{array}{l}\text { County } \\
\text { Tang }\end{array}\end{array}$ & 5.11 & 22534.85 & 0.99 & 39.59 & $\begin{array}{l}\text { QuyangC } \\
\text { ounty }\end{array}$ & 3.33 & 16254.15 & 1.25 & 34.97 \\
$\begin{array}{l}\text { County } \\
\text { Gaoyang County }\end{array}$ & 1.48 & 23593.78 & 1.85 & 26.80 & $\begin{array}{l}\text { Li } \\
\text { County }\end{array}$ & 18.5 & 20363.09 & 1.09 & 38.40 \\
$\begin{array}{l}\text { Rongcheng } \\
\text { County }\end{array}$ & 1.21 & 29233.70 & 1.04 & 39.85 & $\begin{array}{l}\text { Shunping } \\
\text { County } \\
\text { Boye }\end{array}$ & 1.50 & 21673.90 & 1.22 & 32.97 \\
County & 6.76 & 19899.50 & 1.10 & 42.82 \\
\hline
\end{tabular}




\begin{tabular}{llllllllll}
\hline Laiyuan County & 2.09 & 28875.71 & 1.26 & 27.34 & Xiong & 1.36 & 27473.25 & 1.02 & 45.43 \\
Wangdu County & 4.63 & 28476.26 & 1.23 & 41.58 & & & & & \\
\hline
\end{tabular}

(Source: According to Baoding Economic Statistics Yearbook 2017, Hebei Banking Regulatory Bureau websiteand others)

It can be seen from the data in Table 1 a above that there is a large gap between the maximum and minimum values of the 15 counties, indicating that there is a wide gap in the level of inclusive financial development. In terms of financial service convenience, Li County is the best, while Gaoyang County is the worst. Because there are relatively fewer rural financial practitioners inGaoyang. For financial service usage, Fuping County is the best, while Quyang County is the worst. For Quyang County, the per capita deposit and loan amount is less.In terms of financial service development efficiency, Fuping County is the best, while Dingxing County is the worst. The main reason is that Dingxing County has higher GDP, so the amount of deposits and loans per unit GDP is relatively small.For financial service environment, Xiong County is the best, while Fuping County is the worst, mainly because of the low Internet coverage and the urbanization rate needs to be further improved.

According to the Table 1 and formula (4), the IFI of each county of Baoding can be obtained. The results are shown below;

Table 2 the IFI of each county of Baoding

\begin{tabular}{|c|c|c|c|c|c|}
\hline County & IFI & County & IFI & County & IFI \\
\hline $\begin{array}{l}\text { Laishui } \\
\text { County }\end{array}$ & 0.49 & $\begin{array}{l}\text { Rongcheng } \\
\text { County }\end{array}$ & 0.59 & $\begin{array}{l}\text { Quyang } \\
\text { County }\end{array}$ & 0.22 \\
\hline $\begin{array}{l}\text { Fuping } \\
\text { County }\end{array}$ & 0.54 & $\begin{array}{l}\text { Laiyuan } \\
\text { County }\end{array}$ & 0.26 & $\begin{array}{l}\mathrm{Li} \\
\text { County }\end{array}$ & 0.49 \\
\hline $\begin{array}{l}\text { Dingxing } \\
\text { County }\end{array}$ & 0.31 & $\begin{array}{l}\text { Wangdu } \\
\text { County }\end{array}$ & 0.44 & $\begin{array}{l}\text { Shunping } \\
\text { County }\end{array}$ & 0.22 \\
\hline $\begin{array}{l}\text { Tang } \\
\text { County }\end{array}$ & 0.30 & $\begin{array}{l}\text { Anxin } \\
\text { County }\end{array}$ & 0.38 & $\begin{array}{l}\text { Boye } \\
\text { County }\end{array}$ & 0.36 \\
\hline $\begin{array}{l}\text { Gaoyang } \\
\text { County }\end{array}$ & 0.34 & Yi County & 0.12 & $\begin{array}{l}\text { Xiong } \\
\text { County }\end{array}$ & 0.38 \\
\hline
\end{tabular}

The IFI value is between 0 and 1 . The closer it is to 1 , the lower the financial exclusion of the region, and the higher the level of inclusive financial development. Conversely, the closer to 0 indicates the financial exclusion of the region. As shown in Table 3 above, the average IFI index of 15 counties in Baoding is 0.36, of which 8 counties are above the mean level, and 7 counties are below. The highest IFI value is Rongcheng County, which is 0.59; the lowest is Yi County, which is 0.12. It can be seen that the development level of Inclusive Finance in 15 counties is uneven. Comparing Rongcheng County and Yi County, it can be seen that the actual values of the four dimensions of Rongcheng County are greater than YiCounty. Only Rongcheng County and Fuping County's IFI valuesare greater than 0.5, Rongcheng County relies on convenient geographical conditions and the reason for the better development ofFuping County is from the government's strong support in recent years.

\section{Problems in the Development of Rural Inclusive Finance in Baoding}

\subsection{The relatively low level of rural inclusive finance development in Baoding.}

Baoding as a third-tier city with 15 counties,and only half of these counties were urbanized, which reflects the degree of rural economic growth in Baoding is not high. In addition, drawing onthe theory that the IFI is closer to 1, the higher the development level of Inclusive Finance is, the highest value is 0.59 and the lowest value is 0.12 , which indicates that the difference between them is large. And the average level is only 0.36, reflecting the overall rural inclusive financial development level is low. 
Banks and other financial institutions have few outlets and limited types of products.

At present, the major financial institutions in the counties of Baoding are mainly state-owned commercial banks and rural creditunions, whilethe five major state-owned commercial banks points to the cities. Although the government has been introducing policies to encourage these banks to increase their support for rural areas, the big state-owned banks still lack the impetus. Besides, rural credit unions are located in rural areas, they trend to use agriculture-related loans for commercial loans for profit. For the village banks, their scale and scope of operation are small, so that their products can not meet the varied needs of rural finance.

\subsection{Conservative and outdated attitude of peasants towards finance.}

Peasants' attitudeabout finance manifestsin two areas: On one hand, the conservative attitude towards finance means there are less financially related demands. The traditional financial attitude of farmers is aboutbeing economical and being able to generate wealth. Compared with loan, farmers tend to deposit. When there is a need for cash, most farmers prefer neighborhoods to financial institutions. On the other hand, they still hold an outdated view of finance. Going to the nearby branch of banksis the typical choice for them. The cashless mobile paymentandother modern payments are not popular among them as well.To conclude, the reason why the prospect of rural finance is restrained is largely due to the fact that thereare limited amountof financial infrastructure.

The construction of rural financial service facilities is not perfect.

The popularization of Inclusive Financein rural areas needs perfect infrastructure services as a support, while the construction of financial services facilities in rural areas is far from the standard level. Take broadband as an example. The broadband coverage rate of various counties in the Baoding is about $30 \%$ at a low level. On the one hand, it leads to the blind spot of farmers' understanding of financial electronic products, which makes farmers' enthusiasm for financial demand decline On the other hand, the electronic banking business of commercial banks and rural credit unions is blocked, and the development platform of new rural financial institutions such as mutual aid groups and country banks is restricted.

\section{Suggestions on the Development of Rural Inclusive Finance in Baoding}

\subsection{Accelerate the overall development pace of economic and inclusive finance in rural area.}

To promote the development level of rural Inclusive Finance in Baoding, the first thing to do is to accelerate the development of the overall economy and coordinate the urban and rural economy. The development of rural Financial Inclusion requires the joint efforts of society. On the one hand, the government needs to improve the construction of rural financial service facilities. On the other hand, it needs to make financial policies to stimulate financial institutions to support rural areas. As for regulatory agencies,they need to regulate the financing activities of various microfinance companies, country banks, and Mutual aid group. By supervision, the loan process becomes open and transparent, so that it can really contribute to the development of Financial Inclusion.

\subsection{Encourage financial innovation and promote the development of inclusive finance.}

Financial institutions play an indispensable role in promoting the development of rural Financial Inclusion. In order to provide more convenient and sustainable inclusive financial services for small and medium-sized enterprises, farmers and others, the financial institutions should contribute more. On the one hand, according to the characteristics of rural financial services,existent financial institutions need to be innovative to create new models to adapt to the needs of financial marketsand promote the sustainable development of rural Inclusive Finance. On the other hand, different enterprises should be encouraged to participate in the construction of new micro-financial institutions, and private capital should be energized through reasonableand effective competition.

\subsection{Establish financial concepts and foster financial needs.}

As an important participant in the rural Financial Inclusion, farmers should take the initiative to learn financial knowledge, establish financial concepts that adapt to the times. And farmers should 
boldly participate in the use of mobile payment. In addition, the government should increase financial support for vulnerable groups, such asoffering a concessional loan and agricultural subsidy.It is also possible to promote peasant employment to increase farmers' income in terms to expand financial demands.

\section{To Expand Financial Demands}

Improve broadband coverage and accelerate information penetration. With the popularity of the Internet and the application of big data technology, Internet finance has shown great advantages in promoting the development of Financial Inclusion and has become an important supplement to the traditional finance. Informatization means is the only way for the development of Financial Inclusion. Therefore, it is urgent to develop the Internet path. Financial institutions need to use the advantages of Internet finance, timely transform their business models, and achieve a good complementarity between Inclusive Finance and Internet finance. Facing the current situation of low broadband coverage in rural areas, the government can have a interview with the network operators and force the network operators to provide maximum incentives for information construction, making Internet Finance contributes to the development of rural Inclusive Finance.

\section{Acknowledgement}

Project supported by the Science Research Foundation of Hebei Finance University in 2017 (key Project No. DXSKYZ2017001).

\section{References}

[1] Jiao Jinpu, Deputy Director, Research Bureau of the people's Bank of China. Build a multi-level rural financial system[N].China Securities Journal, 2006-03-09 (A04).

[2] Cai Yangping. Evaluation and Analysis of Rural inclusive Financial Development in three Central provinces of Hunan, Hubei and Henan [J]. Agricultural Technology economy, 2015 (02): 42-49.

[3] Zhai Shuai.A study on the Financial Index and its influencing factors in Jiangsuprovince[J]. The monthly financial journal, 2015 (12): 65-69.

[4] Jiao Jinpu, Huang Ting,Wang Tiandu,Zhang Shaohua,Wang Yu.An empirical study on the Development of Inclusive Finance in China [J].Shanghai Financial Department,2015 (04): 12-22.

[5] Qi Yongzhong, Tian Yaqiong.A study on the Development of Rural Inclusive Finance in Ningxia: an empirical Analysis based on IFI Index [J].Ningxia Agricultural and Forestry Science \& Technology, 2016-57 (02): 59-61. 